\title{
Evaluation of genetic similarity and distance among seven Clariid fish populations in Kano Rivers, Nigeria \\ ${ }^{* 1}$ Suleiman, I. O., ${ }^{2}$ Kabir, M., ${ }^{3}$ Bolorunduro, P. I. and ${ }^{4}$ Akinsola, O. M. ${ }^{\prime}$ Department of Animal Science, Bayero University Kano, ${ }^{2}$ Department of Animal Science, Ahmadu Bello University Zaria ${ }^{3}$ National Agricultural Extension and Research Liaison Services, Ahnadu Bello 20 University, Zaria ${ }^{4}$ Department of Theriogenology and Production, University of Jos *Corresponding author: ibro172000@yahoo.com; 08030520867 \\ Abstract
}

A population can only acquire new gene either through the immigration of individuals from surrounding populations. One of the greatest advantages of microsatellite marker is that DNA sequence information is needed to perform the assay. Thus, a study was carried out to evaluate genetic similarity and distance in strains of Clariid species (Clarias gariepinus and Heterobranchus longifilis). In achieving this, 25 blood samples were gotten from Clarias gariepinus and 10 from Heterobranchus longifilis for DNA extraction. DNA were extracted, amplified and scored using seven microsatellite markers. The markers were Cga01, Cga02, Cga03, Cga05, Cga06, Cga09 and Cga10. The gel images were then subjected to molecular analysis using Genealex software to determine their base pairs and evaluate their genetic variability. The populations examined were Clarias gariepinus of River Dudusingaya $(\mathrm{CgD})$, Ghari $(\mathrm{CgG})$, Thomas $(\mathrm{CgT})$, Karaye $(\mathrm{CgK})$, Bagwai $(\mathrm{CgB})$; and Heterobranchus longifilis of River Bagwai (HlB) and Ghari (HlG). Among the populations sampled, the genetic similarity ranged from 0.018 for $\mathrm{CgD}$ and $\mathrm{Cg}$ T populations to 0.079 for $\mathrm{Cg}$ T and $\mathrm{HlG}$ populations. The genetic distance observed in the populations ranged from 0.112 for $\mathrm{CgG}$ and $\mathrm{CgB}$ populations to 0.998 for $\mathrm{CgT}$ and $\mathrm{CgK}$ populations. The Clariid species that were closer indicated that the river locations shared tributaries and the Clariid species exchanged genetic materials over a long period of time. On the other hand, those that were farther apart indicated that they shared little or no tributaries. It can be concluded that the studied populations were not genetically pure but heterogeneous with varying degrees of genetic similarity and distance therefore, there were no. exhibition of genetic uniqueness and the populations were not isolated.

Keywords: Genetic similarity, Genetic distance, Clariid populations

\section{Introduction}

Populations of many species of organisms respond both morphologically and genetically to a changed environment. Within species, genetic diversity is partitioned among and within populations. Long before species decline into extinction, it will suffer a reduction in the level of genetic diversity within and among its populations. Fragmentation causes the formation of small isolated population which are more vulnerable to genetic degradation. While documented extinctions of marine species are rare, the extinction of population (extirpation) is more common (Musick, 1998; Musick et al., 2000). Genetic variation is important for the long-term survival of species; it ensures the fitness of species or populations by giving the species or populations the ability to adapt to changing environment; and lack of genetic variation or too much of homozygosity are detrimental to survival and fitness (Dunham, 2004 ). Homozygosity has been correlated with bilateral asymmetry (fluctuating 


\section{Evaluation of genetic similarity and distance among seven Clariid fish populations}

asymmetry) which is the unbalanced meristic counts of the right and left halves of the body in fishes (Dunham, 2004). A population can only acquire new gene either through the immigration of individuals from surrounding populations or through the process of random mistakes (mutation) of the codes. Apart from these two processes, the genetic diversity of a population is determined by its size and the selective forces acting on it. In general, mutation occurs rarely, although there are cases where high levels of pollution or radiation have been shown to increase mutation rates (Powles et al., 2000). Genetic improvement of aquaculture species offers a substantial opportunity for increased production efficiency, health, product quality and profitability (Davis and Hetzel, 2000). Genetic improvement techniques for delivering genetic gains include definition of breeding objectives, estimation of genetic parameters that described populations and their differences, evaluation of additive and non-additive genetic merit of individuals or families (Davis and Hetzel, 2000). There is a number of different molecular tagging methods which have been designed to study fish populations. The use of biochemical methods such as isozymes and protein electrophoretic techniques for species identification has been widely applied in fish (Yilmaz et al., 2007; Wei and Musa, 2008). Also, the use of molecular methods such as RAPD techniques (Almeida and Sodre, 2002; Quibai et al., 2006), AFLP techniques (Mickett et al., 2003; Simmones et al., 2006) and microsatellite DNA (Perales et al., 2007; Wachirachaikam and Na-Nakron, 2007) has been widely applied in fish characterization. The greatest advantages for RAPD techniques are that it can potentially sample a large number of loci and that no prior DNA sequence information is needed to perform the assay
(Christopher et al., 2004). Therefore, the objective of the study was to evaluate the genetic similarity and distance in Clariid populations in Kano state rivers with a view to unravel their genetic uniqueness.

\section{Materials and methods}

The study was conducted in six selected water bodies in Kano State, namely, River Thomas and River Ghari to the north, River Dudusingaya to the east, River Kano (Tiga section) to the south, River Karaye and Bagwai river to the western part of the state. The first three locations were selected due to their independent flow and their disconnected tributaries. The remaining three locations had the same origin as the Kano River, but the Tiga section of the river flow towards the south while the Karaye river flow towards the western part of the state. The fish samples were identified using an exposition for identification by Moses and Olufeagba, (2009), and confirmed using local names provided by the fishermen. Live fish samples of Clarias gariepinus and Heterobranchus longifilis from the six locations described above were purchased from commercial catches of the fishermen. Thirty-five blood samples (25Clarias gariepinus and 10 Heterobranchus longifilis) were transferred to FTA $^{\circledR}$ Classic Cards (Whatman Bioscience, Maidestone, UK) and left to dry and subsequently used for DNA extraction. The caudal peduncle of the fish samples was severed to drain out blood into the FTA cards. Genomic DNA was extracted according to Agbebi et al. (2013): Five $1.2 \mathrm{~mm}$ disc of FTA $^{\circledR}$ Classic Cards were punched into $1.5 \mathrm{~mL}$ Eppendorf tubes. $1000 \mu \mathrm{l}$ of $100 \mathrm{mM}$ Tris-base and $0.1 \%$ SDS buffer was added and tubes were vortexed gently for $30 \mathrm{~min}$. The supernatant was decanted, thereafter, $500 \mu \mathrm{L}$ of $5 \mathrm{M}$ guanidine thiocyanate was added and vortexed for $10 \mathrm{~min}$. The supernatant was 
decanted again; thereafter, $500 \mu \mathrm{L}$ nuclease-free water was added and vortexed for $10 \mathrm{~min}$ and then the supernatant was decanted. The same volume of nuclease-free water was added and left to stand for $10 \mathrm{~min}$. The supernatant was again decanted and finally, $50 \mu$ lnuclease-free water was added to the discs. The tubes were heated at $90^{\circ} \mathrm{C}$ for $10 \mathrm{~min}$ in a thermocycler to complete extraction. The DNA concentration was further diluted in 1:20 ratio to remove impurities and prevent smearing.

\section{Gel preparation}

\section{DNAAmplification and scoring}

DNA was amplified using polymerase chain reaction (PCR). PCR was carried out in $10 \mu 1$ reaction volumes containing 20 to 40nggenomic DNA, $2 \mu 15 x$ Taq mastermix of Taq DNA polymerase, dATP, dCTP, dGTP, dTTP, $\left(\mathrm{NH}_{4}\right)_{2} \mathrm{SO}_{4}, \mathrm{MgCl}_{2}$, Tween-20, Nonidet P-40, red dye, gel loading buffer, stabilizers, $0.3 \mu \mathrm{l}$ each of the forward and reverse primer sets and $5.9 \mu 1$ of PCR grade water. Seven microsatellite markers isolated by Galbusera et al. (1996) were used as primers. The primers were Cga01, Cga02, Cga03, Cga05, Cga06, Cga09 and Cga10. Amplifications was carried out in a thermocycler as follows: 1 cycle at $94^{\circ} \mathrm{C}$ (5min) for pre-denaturation, 35 cycles at $94^{\circ} \mathrm{C}(30 \mathrm{sec})$ for denaturation, 35 cycles at $55^{\circ} \mathrm{C}(30 \mathrm{sec})$ for annealing, 35 cycles at $72^{\circ} \mathrm{C}(30 \mathrm{sec})$ for extension and 1 cycle at $72^{\circ} \mathrm{C}(5 \mathrm{~min})$ for final extension to complete amplification. PCR condition for each marker was optimized.

\section{Electrophoresis}

Electrophoresis was conducted on 2\% Agarose gel containing a negative control to detect potential PCR contamination, and each gel contained a positive control using a sample that previously had been genotyped in order to standardize allele scoring among gels. Scoring was done by comparison to 8 bp standard DNA ladder with the aid of gel analyser.

\section{Data analysis}

To quantify the extent of molecular variation, locus-by-locus analysis of molecular variance (AMOVA) was performed using Genealex 6.4. The resolve bands were subjected to Genealex 6.4 software to determine their base pairs and for molecular characterization.

\section{Results and discussion \\ Genetic similarity and relatedness}

The similarity values of the population of Clariid species studied is presented in Table 1. The table showed that Clarias gariepinus from River Dudusingaya were related to those of River Ghari with a similarity value of 0.040, River Thomas with 0.018 and River Bagwai with 0.060. The Clarias gariepinus from River Ghari were related to those of River Karaye with a value of 0.040 and River Bagwai with 0.044. They were also related to Heterobrabchus longifilis of River Bagwai with a similarity value of 0.026. Heterobranchus longifilis had a relationship with Clarias gariepinus of River Thomas and River Karaye with values 0.070 and 0.066 , respectively. The Clarias gariepinus of River Thomas were related to those of River Karaye with 0.018 and Hetrobranchus longifilis of River Ghari with 0.079 . Others with values 0.000 were not related meaning that there were no tributaries connecting them. The unbiased genetic similarity values give the relatedness when all sources of error are removed from analysis. Table 2 gives the similarity values and confirmed the values in Table 1 except that the values differed in strength. The result of the Nei's genetic similarity showed that some of the populations were not related at all, indicating that there was no gene exchange between them (0.000). The populations with values ranged from 0.018 to 0.079 had 


\section{Evaluation of genetic similarity and distance among seven Clariid fish populations}

some level of genetic similarity among them. These results are in agreement with the findings of Agbebi et al. (2013) with Heterobranchus bidorsalis and Clarias gariepinus strains. The close relationship between the strains had been emphasized by Teugels et al. (1990) in a revisionary study using osteological features. Agnese et al. (1997b) reported genetic variation at 25 protein and eight microsatellite loci, and two mitochondrial (mtDNA) segments in two sympatric Clariid strains from Senegal River. Results from this experiment were in congruent with those of Rognon et al. (1998) in a morphometric and the allozyme study of nine populations of Clarias gariepinus and seven populations of Clarias anguillaris to quantify their intra and interspecific variation using Clarias albopunctatus and Heterobranchus longifilis as outgroups.

Table 1: Nei's Genetic Similarity values among the investigated populations

\begin{tabular}{llllllll}
\hline & $\mathrm{CgD}$ & $\mathrm{CgG}$ & $\mathrm{CgB}$ & $\mathrm{CgT}$ & $\mathrm{CgK}$ & $\mathrm{HlG}$ & $\mathrm{HlB}$ \\
\hline $\mathrm{CgD}$ & 1.000 & & & & & & \\
$\mathrm{CgG}$ & 0.040 & 1.000 & & & & & \\
$\mathrm{CgB}$ & 0.060 & 0.044 & 1.000 & & & & \\
$\mathrm{CgT}$ & 0.018 & 0.000 & 0.020 & 1.000 & & & \\
$\mathrm{CgK}$ & 0.000 & 0.040 & 0.000 & 0.018 & 1.000 & & \\
$\mathrm{HlG}$ & 0.000 & 0.000 & 0.000 & 0.079 & 0.000 & 1.000 & \\
$\mathrm{HlB}$ & 0.000 & 0.026 & 0.000 & 0.070 & 0.066 & 0.000 & 1.000 \\
\hline
\end{tabular}

$\overline{C g=C l a r i a s}$ gariepinus; $\mathbf{H l}=$ Heterobranchus longifilis.; D-River Dudusingaya; G-River Ghari, B-River Bagwai, T-River Thomas, K- River Karaye

Table 2: Nei's Unbiased Similarity values among the investigated populations

\begin{tabular}{|c|c|c|c|c|c|c|c|}
\hline & $\mathrm{CgD}$ & $\mathrm{CgG}$ & $\mathrm{CgB}$ & $\mathrm{CgT}$ & $\mathrm{CgK}$ & $\mathrm{HIG}$ & HIB \\
\hline $\mathrm{CgD}$ & 1.000 & & & & & & \\
\hline $\mathrm{CgG}$ & 0.080 & 1.000 & & & & & \\
\hline $\mathrm{CgB}$ & 0.125 & 0.107 & 1.000 & & & & \\
\hline $\mathrm{CgT}$ & 0.032 & 0.000 & 0.043 & 1.000 & & & \\
\hline $\mathrm{CgK}$ & 0.000 & 0.091 & 0.000 & 0.037 & 1.000 & & \\
\hline $\mathrm{HlG}$ & 0.000 & 0.000 & 0.000 & 0.065 & 0.000 & 1.000 & \\
\hline HlB & 0.000 & 0.057 & 0.000 & 0.137 & 0.143 & 0.000 & 1.000 \\
\hline
\end{tabular}

Karaye

\section{Genetic distance}

The genetic distance of the population studied are presented in table 3. Nei's genetic distances among all populations ranged from 0.112 ( $\mathrm{CgG}$ vs $\mathrm{CgB}$ ) to 0.998 (CgT vs $\mathrm{CgK}$ ). The Table shows that Clarias gariepinus of River Dudusingaya were genetically closer to Clarias gariepinus of River Ghari with value 0.223 while they were much more genetically distanced from those of River Tiga with 0.907 and River Bagwai with 0.816. Clarias gariepinus of River Ghari had genetic closeness to those of River Karaye (0.214), River Bagwai (0.112) and Heterobranchus longifilis of River Bagwai (0.667). Heterobranchus longifilis of River Bagwai shared genetic attributes with Clarias gariepinus of River Tiga (0.659) and River Karaye (0.725). Clarias gariepinus of River Tiga genetically distanced to those of River Karaye (0.998) and River Bagwai (0.897), but close to Heterobrancus longifilis of River Ghari (0.544).

The unbiased genetic distance values give the genetic relatedness when all sources of error are removed from analysis. Table 4 gives the unbiased genetic distance values and confirmed the values in Table 3 except that the values differed in strength. Genetic 


\section{Suleiman, Kabir, Bolorunduro and Akinsola}

distance measures the genetic divergence between species or between populations within a species as indicated by Nei's genetic distance values, Fst values, mean fixation index and hierarchical clustering dendrogram. The results of this study showed that some of the populations were genetically close while some were farther apart indicating that those that were close might have shared some tributaries and connection in terms of the movement or flow of the water bodies. Those that were farther apart might have some level of distinctiveness in terms of their habitat or there were little or no connection between the water bodies. The results were in agreement with the reports of some authors (Abban and Skibinski, 1988; Agnese, 1989; 1991; Agbebi et al., 2013) on aquatic organisms. Agnese (1989) reported genetic distances varying from 0.271 to 0.916 in the genus Chrysichthys; Abban and Skibinski (1988) reported a distance range of 0.88 to 1.14 between Eutropius niloticus and Schilbe mystus. Agnèse (1991) reported range value of 0.003 to 0.112 for populations of Chrysichthys auratus while Agbebi et al. (2013) reported 0.84 to 0.89 in Clarias gariepinus and heterobranchus bidorsalis.

Table 3: Nei's Genetic Distance among populations of two clariid strains

\begin{tabular}{llllllll}
\hline & $\mathrm{CgD}$ & $\mathrm{CgG}$ & $\mathrm{CgB}$ & $\mathrm{CgT}$ & $\mathrm{CgK}$ & $\mathrm{HlG}$ & $\mathrm{HlB}$ \\
\hline $\mathrm{CgD}$ & 0.000 & & & & & & \\
$\mathrm{CgG}$ & 0.223 & 0.000 & & & & & \\
$\mathrm{CgB}$ & 0.816 & 0.112 & 0.000 & & & & \\
$\mathrm{CgT}$ & 0.907 & $*$ & 0.897 & 0.000 & & & \\
$\mathrm{CgK}$ & $*$ & 0.214 & $*$ & 0.998 & 0.000 & & \\
$\mathrm{HIG}$ & $*$ & $*$ & $*$ & 0.544 & $*$ & 0.000 & \\
$\mathrm{HlB}$ & $*$ & 0.667 & $*$ & 0.659 & 0.725 & $*$ & 0.000 \\
\hline
\end{tabular}

* = undefined, $\mathbf{C g}=$ Clarias gariepinus; $\mathbf{H l}=$ Heterobranchus longifilis.; D-River Dudusingaya; G-River Ghari, B-River Bagwai, T-River Thomas, K- River Karaye

Table 4: Nei's Unbiased Genetic Distance among populations of two clariid strains

\begin{tabular}{llllllll}
\hline & $\mathrm{CgD}$ & $\mathrm{CgG}$ & $\mathrm{CgB}$ & $\mathrm{CgT}$ & $\mathrm{CgK}$ & HlG & HlB \\
\hline $\mathrm{CgD}$ & 0.000 & & & & & & \\
$\mathrm{CgG}$ & 0.523 & 0.000 & & & & & \\
$\mathrm{CgB}$ & 0.790 & 0.235 & 0.000 & & & & \\
$\mathrm{CgT}$ & 0.429 & $*$ & 0.140 & 0.000 & & & \\
$\mathrm{CgK}$ & $*$ & 0.401 & $*$ & 0.307 & 0.000 & & \\
$\mathrm{HIG}$ & $*$ & $*$ & $*$ & 0.736 & $*$ & 0.000 & \\
$\mathrm{HlB}$ & $*$ & 0.857 & $*$ & 0.971 & 0.943 & $*$ & 0.000 \\
\hline
\end{tabular}

* = undefined, $\mathbf{C g}=$ Clarias gariepinus; $\mathbf{H l = H e t e r o b r a n c h u s ~ l o n g i f i l i s . ; ~ D - R i v e r ~ D u d u s i n g a y a ; ~ G - R i v e r ~ G h a r i , ~ B - R i v e r ~ B a g w a i , ~ T - R i v e r ~}$ Thomas, K- River Karaye

\section{Conclusion}

The study showed that the populations were not genetically pure but heterogeneous population with varying degrees of genetic similarity and distance. Based on genetic distance and similarity, and high level of heterozygosity, it is better to employ all the loci as basis for selection and cross breeding except $\mathrm{Cga09}$ so as to ensure the highest gain from selection

\section{References}

Abban, E. K. and Skibinski, D. O. F. 1988. Protein Variation in Schilbe mystus and Eutropius niloticus (Ruppel) (Pisces Siluriforms) in the Volta basin of Ghana, WestAfrica. Aquaculture and Fish 
Evaluation of genetic similarity and distance among seven Clariid fish populations

Management 19:25-37

Agbebi, O. T., Ilaboya, D. E. and Ad ebambo, A. O. 2013. Preliminary characterization of genetic strains in clariid species, Clarias garepinus and Heterobranchus bidorsalis using microsatellite markers. African Journal of Biotechnology, 12(4): 364-369.

Agnèse, J. F. 1989. Différenciation génétique de plusieurs espèces de Silurifonnes Ouest- Africains ayantu $\mathrm{n}$ intérêt pour 'aquaculture. Ph.D. Thesis, University of Montpellier, France. Pp 87-89.

Agnèse, J. F. 1991. Taxonomic status and genetic differentiation among West African populations of the Chrysichthys auralus complex (Pisces, Siluriformes), based on protein electrophoresis. Aquaculture and Fisheries Management, 22: 229-237.

Agnèse, J. F., Teugels, G. G., Galbusera, P., Guyomard, R. and Volckaert, F. 1997. Morphometric and genetic characterization of sympatric populations of Clarias gariepinus and Clarias anguillaris in Senegal. Journal of Fish Biology. 50: 11431157.

Almeida, F. S. and Sodre, L. M. K. 2002. Comparative study by RAPD analysis of six species of the $P$ i m e lodide a f a m i $1 \mathrm{y}$ (Osteichthyyes, Siluriformes) from the Tibagi River, State of Parana, Brazil. Maringa, 24:513-517.

Christopher, W., Theodorakis, I. and John, W. 2004. Molecular characterization of contaminantindicative RAPD markers. Ecotoxicology, 13: 303-309.

Davis, G. P. and Hetzel, D. J. S. 2000. Integrating molecular genetic technology with traditional approaches for genetic improvement in aquaculture species. Aquaculture Research, 31: 3-10.

Dunham, R. A. 2004 Aquaculture and Fisheries Biotechnology: Genetic Approaches. CABI Publishing, CABI International, Wellingford, Oxfordshire. OX10 8DE UK. ISBN Number: 0851995069. www.cabi-publishing.org

Mickett, K., Morton, C., Feng, J., Li, P., Simmones, M., Cao, D.A., Dunham, R. A. and Lui, Z. 2003. Assessing genetic diversity of domestic population of channel catfish (Letalurus punctatus) in Alabama using AFLP markers. Aquaculture, 228: 91-105.

Moses, Y. and Olufeagba, S. O. 2009. An Exposition on Field Identification of Clariid Catfishes as an Important Tool in Fish Breeding and Genetics. Manual of the National Institute for Freshwater Fisheries Research, New Bussa, Niger state.

Musick, J. A. 1998. Endangered marine fishes: criteria and identification of North American stocks at risk. Fisheries, 23: 28-30.

Musick, J., Burgess, G., Cailliet, G., Camhi, M. and Fordham, S. 2000. Management of sharks and their relatives (Elasmobranchii). Fisheries, 25:9-13.

Perales, E., Sifuentes, A. and Garcia, J. 2007. Microsatallite variability analysis in farmed catfish (Letalurus punctatus) from Tamau lipas, Mexico. Genetics and molecular Biology, 30: 570-574.

Powles, H., Bradford, M. J., Bradford, R. G., Doubleday, W. G., Innes, S. and Levings, C. D. 2000. 


\section{Suleiman, Kabir, Bolorunduro and Akinsola}

Assessing and protecting endangered marine species. ICES Journal of Marine Science, 57: 669-676.

Quibai, Z., Fengbo, I., Li, Z. and Jianfang, G. 2006. RAPD markers between yellow catfish (Pelteobagrus fulvidraco) and long whiskers yellow catfish (Pelteobagrus enpogen) AetaHydrobiologica-sinica, 30:482485.

Rognon, X., Teugels, G. G., Guyomard, R., Galbusera, P, Andriamanga, M, Volckaert, F. and Agnese J. F. 1998. Morphometric and allozyme variation in the African catfishes Clarias gariepinus and Clarias anguillaris. Journal of Fish Biology 53:192-207.

Simmones, M., Mickett, K., Kucuktas, H., Li, P., Dunham, R. A. and Lui, J. 2006. Comparison of domestic and wild channel catfish (Letalurus punctatus) populations provides no evidence for genetic impact. Aquaculture, 252: 133-146.
Teugels, G. G., Denayer, T. and Legendre U. 1990. Systematic revision of the African catfish genus Heterobranchus Geohrey saint Hilaire 1809 (Pisces lasiidae) Zoological journal of the Linnean Society 92; 237-257

Wachirachaikam, A. and Na-Nakorn, U. 2007. Subject: Fisheries. Proceedings of the 45th Kasetsart University Annual Confernce, Kasetsart, pp: 82-89.

Wei, L. and Musa, N. 2008. Phenotyping, genotyping and whole cell profiling of Edwardstella tarda isolated from cultivated and natural habitat fresh water fish. American/EurAsian Journal of Agricultural and Environmental Science 3: 681-691

Yilmaz, M., Yilmaz, H. R. and Alas, A. 2007. An electrophoresis taxonomic study on serum proteins of Acanthobrama marmid, Leuciscus cephalus and Chondrostoma regium. Asia Journal of Bioscience, I: 22-27.

Received: $14^{\text {th }}$ April, 2019

Accepted: $25^{\text {th }}$ July, 2019 